\title{
Faktor yang Mempengaruhi Manajemen Laba dimoderasi oleh Ukuran Perusahaan
}

\author{
(Studi pada Perusahaan Perbankan yang Terdaftar di BEI)
}

\author{
Hendi $^{1}$, Erika $^{2}$ \\ Universitas Internasional Batam ${ }^{1,2}$ \\ hendi.chan@uib.ac.id ${ }^{1842166 . e r i k a @ \text { uib.edu }^{2}}$
}

*Corresponding Author

Diajukan : 10 Januari 2022

Disetujui : 17 Januari 2022

Dipublikasi : 21 Januari 2022

\begin{abstract}
Earnings management occurs when there is a separation of positions and a comparison of interests between the owner and the manager. Earnings management is influenced by known independent variables for the purpose of this research. The independent variables used in this study are institutional ownership, managerial ownership, the proportion of independent commissioners, directors, audit committees, audit quality, independent boards, leverage, profitability. The moderating variable used in this research is company size. The dependent variable used in this study is earnings management. The sample that is part of the research is a company that operates in the banking sector and listed in Indonesian Stock Exchange. This study uses secondary data with the banking sector population in 2016-2020 as many as 44 companies and the number of the samples taken based purposive sampling method is as many as 39 companies with 195 data. The data from this study were processed using two programs, namely SPSS for descriptive statistics and PLS SEM to prove the accuracy, suitability, and impact of the existing variables. The results of the study found that institutional ownership, managerial ownership, the proportion of independent commissioners, directors, audit committees, audit quality, independent boards, leverage, profitability, firm size were able to have a significant positive effect on earnings management.
\end{abstract}

Keywords: Earnings Management, Company Size, Institutional Ownership, Managerial Ownership, Leverage

\section{PENDAHULUAN}

Beberapa kasus yang berkaitan dengan manajemen laba selalu terjadi pada perusahaan perbankan di Indonesia. Kasusnya yang melanda Bank Century di mana manajemen melakukan rekayasa laporan keuangan supaya perusahaan menunjukkan modal yang sesuai, selain itu hal ini dilakukan untuk memperoleh dana penyelamatan dari Menteri Keuangan Sri Mulyani (Ariesanti, 2015). Per 28 januari 2008 ternyata modal Bank Centruy diduga -132,5\%. Bank Indonesia (BI) tidak memperbolehkan mengeliminasi $100 \%$ yang berhubungan dengan surat-surat berharga (Oktariani \& Africano, 2017).

Kasus yang lain mengenai Bank Bukopin yang diperkirakan memalsukan informasi kartu kredit sepanjang kurang lebih 5 tahun yang lalu. Kartu kredit yang sukses dimodifikasi sebesar 100. 000 jumlah kartu kredit. Permasalahan ini dapat lulus dari pengecekan audit sepanjang bertahuntahun, baik dari audit dalam Bukopin, ataupun dari Kantor Akuntan Publik, Bank Indonesia, serta Otoritas Jasa Keuangan (OJK). Perihal ini diakibatkan oleh lemahnya kemampuan pihak-pihak pejabat Bank Bukopin (Ayem \& Yuliana, 2019). Laporan keuangan Bank juga dilakukan audit oleh pengaudit yang afiliasi dengan salah satu big four pengaudit global ERNST \& Young, yakni KAP Purwanto, Sungkoro serta Surja (Maulidah \& Santoso, 2020). 
Bank adalah salah satu organisasi yang dapat menampung anggaran dari rakyat berbentuk dana serta menyalurkan lagi berbentuk angsuran atau bentuk yang lain dalam rangka tingkatkan derajat hidup masyarakat. Setelah perusahaan melakukan aktivitas, pada satu periode tertentu, perusahaan akan membuat sebuah laporan yang disebut sebagai laporan keuangan (Fitri et al., 2018). Laporan keuangan merupakan akar dari sebuah informasi yang memberikan penjelasan tentang kondisi dan kinerja suatu perusahaan bagi perusahaan maupun diluar dari perusahaan tersebut. Salah satu elemen penting serta menjadi hal khusus untuk diperhatian lebih oleh pihak - pihak terlibat adalah laba (Agustia, 2013).

Pentingnya penelitian manajemen laba dilakukan untuk mengetahui apakah praktik memanipulasi keuntungan masih perusahaan lakukan (Wiyadi et al., 2017). Banyaknya kasus yang terkait dengan manajemen laba terhadap laporan keuangan menyebabkan menurunnya tingkat keyakinan masyarakat pada kualitas auditor (Maulidah \& Santoso, 2020). Aktivitas manajemen memberikan dampak negatif bagi pihak investor maupun kreditur dalam melakukan investasi kekayaan pada perusahaan tersebut, selain investor dan kreditur hal ini juga memberikan dampak bagi pemilik perusahaan (Jao \& Pagalung, 2011). Manajemen laba ini diduga terjadi dikarenakan kurangnya pengaplikasian pengelolaan perusahaan yang baik.

\section{Penelitian Terdahulu}

\section{STUDI LITERATUR}

\section{Pengaruh Kepemilikan Institusional terhadap Manajemen Laba}

Wimelda dan Chandra (2018) mengungkapkan fungsi pengawasan dapat dicapai melalui investor institusional, ini dikarenakan investor institusional cenderung lebih memiliki wewenang untuk melakukan pengawasan dan pengendalian manajemen untuk mencapai kepentingan bagi para pemegang saham. Penelitian oleh Istikhomah dan Widyawati (2018), Sumbari et al. (2017), Dina dan Dul (2012), Kusumaningtyas (2012), Saidu et al. (2017), Djamaludin dan Handayani (2018) membuktikan kepemilikan institusional dalam mempengaruhi signifikan positif pada manajemen labanya.

$\mathrm{H}_{1} \quad$ Kepemilikan institusional memiliki pengaruh signifikan positif terhadap manajemen laba

\section{Pengaruh Kepemilikan Manajerial terhadap Manajemen Laba}

Kepemilikan manajerial sebagai keseimbangan pemegang sahamnya berperan serta dalam mengambil keputusan. Studi oleh Fitri et al (2018), Mahiswari dan Nugroho (2014), Agustia (2013), Abata dan Migiro (2016), Amperaningrum dan Sari (2013), Ariesanti (2015), Haslinda et al. (2019), Jao dan Pagulung (2011), Jensen dan Meckling (2016), Lidiawati dan Asyik (2016) membuktikan kepemilikan manajerial dalam mempengaruhi signifikan positif pada manajemen labanya.

$\mathbf{H}_{2} \quad$ Kepemilikan manajerial memiliki pengaruh signifikan positif terhadap manajemen laba

\section{Pengaruh Proporsi Dewan Komisaris Independen terhadap Manajemen Laba}

Dewan komisaris merupakan suatu dewan yang tugasnya guna mengawasi serta memberi nasihat untuk direktur (Fitri et al., 2018). Studi oleh Kodriyah et al (2017), Ayem dan Yuliana (2019), Karina dan Sufiana (2020), Oktariani dan Africano (2017), Susanto dan Christiawan (2016) membuktikan proporsi dewan komisaris independen dalam mempengaruhi signifikan positif pada manajemen labanya.

$\mathrm{H}_{3} \quad$ Proporsi dewan komisaris independen memiliki pengaruh signifikan positif terhadap manajemen laba

\section{Pengaruh Komite Audit terhadap Manajemen Laba}

Komite audit sebagai organisasi tambahan yang memiliki fungsi guna membantu mengerjakan fungsi serta tugas yang diberikan oleh dewan komisaris (Istikhomah \& Widyawati, 2018). Komite audit mampu membantu meminimalisir praktik manajemen laba didalam sebuah perusahaan, tetapi 
pada penelitian terdahulu mendeskripsikan tidak adanya jaminan penurunan penerapan manajemen laba yang dibuat perusahaan.

Studi oleh Yogi et al. (2016), Dina dan Dul (2012), Kusumaningtyas (2012), Saidu et al. (2017), Djamaludin dan Handayani (2018) membuktikan bahwa komite audit dalam mempengaruhi secara signifikan positif pada manajemen keuntungan.

$\mathrm{H}_{4} \quad$ Komite audit memiliki pengaruh signifikan positif terhadap manajemen laba

\section{Pengaruh Dewan Direktur terhadap Manajemen Laba}

Dewan direktur sebagai pemangku kepentingan yang dapat mempengaruhi besarnya suatu keputusan hasil keuangan dan operasi perusahaan (Palma \& Purba, 2020). Riset oleh Mayliza et al. (2019), Swastika (2013), Dwiridotjahjono et al. (2019), Fodio et al. (2013), Karuniasih (2013), Laksana (2015), Palma dan Purba (2020), Pratiwi et al. (2016), Putra (2019), Ricardo dan Faisal (2015) membuktikan bahwa dewan direktur dalam memberi pengaruh dengan positif signifikan pada manajemen laba.

\section{H5 Dewan direktur memiliki pengaruh signifikan positif terhadap manajemen laba}

\section{Pengaruh Dewan Independen terhadap Manajemen Laba}

Dewan perusahaan memiliki tanggungjawab manajemen pemantauan untuk melindungi para pemegang saham (Abata \& Migiro, 2016). Pengkajian manajemen laba yang dilaksanakan oleh Mandalika dan Hermanto (2020), Maulidah dan Santoso (2020), Oktariani dan Africano (2017), Palma dan Purba (2020), Pratiwi et al. (2016), Ricardo dan Faisal (2015) membuktikan bahwa dewan independen dalam mempengaruhi secara signifikan positif pada manajemen laba.

$\mathrm{H}_{6}$ Dewan independen memiliki pengaruh signifikan positif terhadap manajemen laba

\section{Pengaruh Kualitas Audit terhadap Manajemen Laba}

Kualitas audit yaitu orang yang berkualifikasi tertentu ketika mengaudit pelaporan keuangan dan segala tindakan dalam perusahaan atau lembaga (Abata \& Migiro, 2016). Laporan yang diaudit diyakini akan menambah keyakinan publik terhadap informasi yang diberikan perusahaan. Studi oleh Haslinda et al. (2019), Jao dan Pagulung (2011), Jensen dan Meckling (2016), Karina dan Sufiana (2020), Karuniasih (2013), Laksana (2015) membuktikan bahwa kualitas audit dalam mempengaruhi secara signifikan positif pada manajemen laba.

$\mathrm{H}_{7} \quad$ Kualitas audit memiliki pengaruh signifikan positif terhadap manajemen laba

\section{Pengaruh Leverage terhadap Manajemen Laba}

Leverage sebagai teknik apapun dengan melibatkan penggunaan hutang (dana pinjaman) daripada ekuitas dalam pembelian aset, dengan harapan akan membawa keuntungan bagi perusahaan (Muhammadinah, 2016). Studi oleh Istikhomah dan Widyawati (2018), Fitri et al (2018), Mahiswari dan Nugroho (2014), Agustia (2013), Kodriyah et al (2017), Mayliza et al. (2019), Swastika (2013), Abata dan Migiro (2016), Amperaningrum dan Sari (2013), Ariesanti (2015), Ayem dan Yuliana (2019) membuktikan bahwa leverage dalam mempengaruhi secara signifikan positif pada manajemen laba.

\section{$\mathrm{H}_{8} \quad$ Leverage memiliki pengaruh signifikan positif terhadap manajemen laba}

\section{Pengaruh Profitabilitas terhadap Manajemen Laba}

Profitabilitas yaitu daya sebuah badan usaha demi memperoleh keuntungan dari penghasilan perusahaan berbentuk hasil penjualan, jumlah aktiva dan juga modal sendiri (Haslinda, Mardani \& Wahono, 2019). Studi oleh Palma dan Purba (2020), Pratiwi et al. (2016), Ricardo dan Faisal (2015), Shohlihin dan Ratmono (2020), Sulistyanto (2014) membuktikan bahwa profitabilitas dalam memengaruhi signifikan positif pada manajemen labanya.

\section{$\mathrm{H}_{9} \quad$ Profitabilitas memiliki pengaruh signifikan positif terhadap manajemen laba}




\section{Ukuran Perusahaan dapat menjadi variabel moderasi dalam mempengaruhi Manajemen Laba}

Ukuran perusahaan sebagai indikator yang mana ukuran perusahaan bisa diklasifikasikan Fitri et al (2018). Didalam penelitian Amijaya dan Prastiwi (2013) menjelaskan perusahaannya yang besar mempunyai motivasi yang besar guna meratakan keuntungan dibanding perusahaan kecil, sehingga pada penelitiannya menghasilkan variable ukuran perusahaannya berketerhubungan signifikan positif terhadap manajemen labanya (Istikhomah \& Widyawati, 2018).

Studi oleh Yasser dan Soliman (2018), Yogi et al. (2016), Dina dan Dul (2012), Lidiawati dan Asyik (2016), Mandalika dan Hermanto (2020) membuktikan ukuran perusahaannya dalam mempengaruhi secara signifikan positif pada manajemen laba.

$\mathrm{H}_{10}$ Ukuran perusahaan dapat memoderasi kepemilikan institusional, kepemilikan manajerial, proporsi dewan komisaris independen, komite audit, dewan direktur, dewan independen, kualitas audit, leverage, profitabilitas terhadap manajemen laba

\section{Kerangka Penelitian}

Kerangka pemikiran pada studi ini yaitu beberapa faktor penyebab terjadinya manajemen laba. Studi ini adalah replikasi dari studi dari Fitri et al. (2018) dan Swastika (2013). Di mana kerangka pemikiran teoritisnya dapat diketahui dalam bagan berikut:

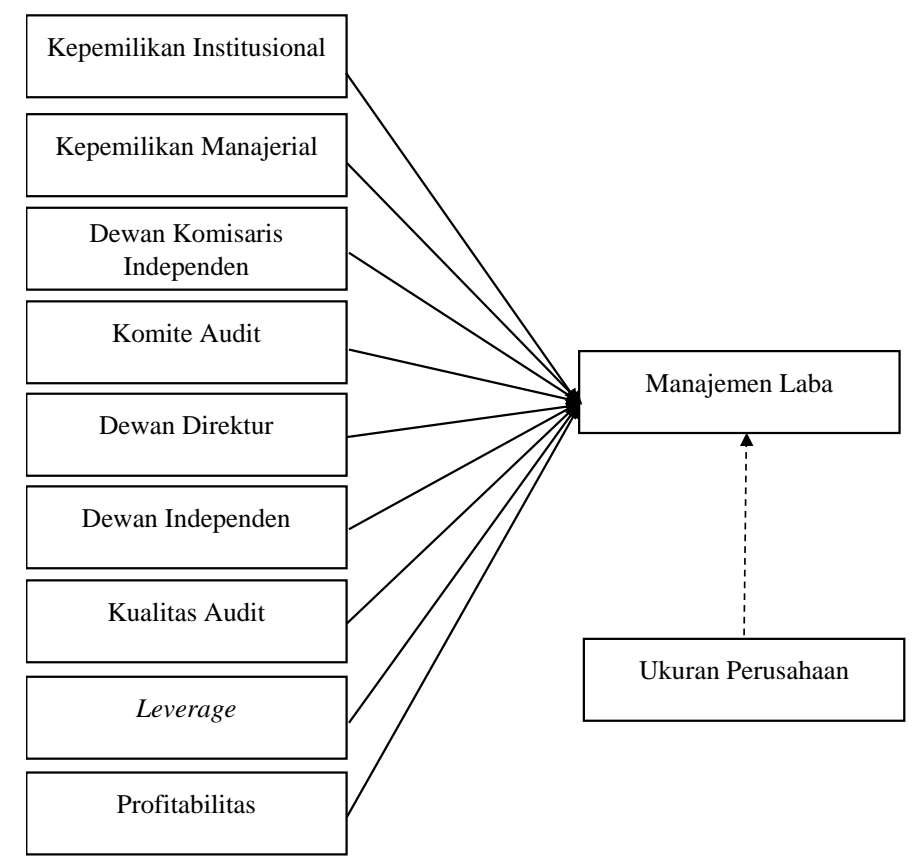

Gambar 1. Model Penelitian

Sumber gambar : Data sekunder diolah (2021)

\section{METODE}

Riset ini bertujuan untuk mengembangkan kembali penelitian sebelumnya yang bersifat kuantitatif, artinya yaitu data yang ada bebentuk angka atau bilangan. Di riset ini, memakai jenis data yang sifatnya time series dikarenakan datanya yang didapatkan melebihi satu periode, yakni tahun 2016-2020. Analisis data yang dilakukan yaitu Teknik analisis SEM ( Structural Equation Model ). Sebagai populasi penelitiannya yakni perusahaan perbankan yang terdapat di BEI. Datadata itu bisa didapatkan diberbagai website seperti http://www.idx.co.id serta website resminya dari perusahaannya. Teknik pengambilan sample di riset ini dengan penentuan pertimbangan sesuai tujuan penelitian atau dikatakan purposive sampling. 
Owner: Riset \& Jurnal Akuntansi

e-ISSN : 2548-9224|p-ISSN : 2548-7507

Volume 6 Nomor 1, Januari 2022

\section{Manajemen Laba}

Pada riset ini peneliti memakai rumus Modified Jones Model (model jones dimodifikasi). Modelnya tersebut banyak diterapkan ke beberapa studi-studi akuntansi sebab dianggap model yang terbaik untuk melakukan deteksi manajemen laba serta mendapatkan hasil paling robust. Serupa dengan model manajemen laba dengan basis aggregate accruals lainnya model tersebut memakai discretionary accruals menjadi proksi manajemen labanya (Fitri et al., 2018). Pengukuran manajemen laba adalah:

$$
\mathrm{TAC}=\mathrm{Nit}-\mathrm{CFOit}
$$

Angka TA (total accrual) yang diestimasikan melalui rumus regresi ordinary least squares (OLS) yaitu:

$$
\text { TA it } / \text { A it- } 1=\beta 1(1 / \text { A it- } 1)+\beta 2(\Delta \text { Revt } / \text { A it- } 1)+\beta 3(\text { PPEt } / \text { A it- } 1)+e
$$

melalui penggunaan koefisiensi regresi, angka non discretionary accruals (NDA) bisa diketahui menggunakan persamaan:

$\mathrm{NDA}$ it $=\beta 1(1 / \mathrm{A}$ it -1$)+\beta 2(\Delta \mathrm{Revt} / \mathrm{A}$ it $-1-\Delta \operatorname{Rect} / \mathrm{A}$ it $-1+\beta 3(\mathrm{PPEt} / \mathrm{A}$ it- 1$)$

kemudian discretionary accrual (DA) bisa ditentukan melalui:

$$
\text { DA it }=\text { TA it } / \mathrm{A} \text { it }-1-\mathrm{NDA} \text { it }
$$

Dimana :

NDA it $=$ Non Discretionary Accruals perusahaan i dalam rentang tahun ke $\mathrm{t}$

DA it = Discretionary Accruals perusahaan i dalam rentang tahun ke $\mathrm{t}$

$\mathrm{N}$ it $=$ Laba bersih perusahaan i dalam rentang tahun ke- $\mathrm{t}$

TA it $=$ Total akrual perusahaan i dalam rentang tahun ke $\mathrm{t}$

$\mathrm{CFO}$ it $=$ Aliran kas dari kegiatan operasi perusahaan i dalam rentang tahun ke- $t$

A it- 1 = Total aktiva perusahaan i dalam rentang tahun ke t-1

$\Delta$ Revt $=$ Perubahan pendapatan perusahaan i dalam rentang tahun ke $t$

PPEt $=$ Aktiva tetap perusahaan i dalam rentang tahun ke $\mathrm{t}$

\begin{tabular}{|c|c|}
\hline Keterangan & Rumus \\
\hline Kepemilikan Institusional & $\frac{\text { Jumlah saham yang dimiliki investor }}{\text { Jumlah saham yang beredar }} \times 100 \%$ \\
\hline Kepemilikan Manajerial & $\frac{\text { Jumlah saham yang dimiliki manajemen }}{\text { Jumlah saham yang beredar }} \times 100 \%$ \\
\hline $\begin{array}{l}\text { Proporsi dewan komisaris } \\
\text { independen }\end{array}$ & $\frac{\text { Jumlah dewan komisaris diluar perusahaan }}{\text { Jumlah dewan komisaris }} \times 100 \%$ \\
\hline Komite audit & $\Sigma$ Anggota Komite audit di perusahaan \\
\hline Dewan direktur & $\Sigma$ Anggota Direktur di perusahaan \\
\hline Dewan independen & $\Sigma$ Anggota Independen di perusahaan \\
\hline Kualitas audit & $\begin{array}{c}1 \text { apabila dilakukan audit oleh KAP Big four; } 0 \text { apabila } \\
\text { dilakukan audit oleh pihak selain dari KAP Big four. Kriteria } \\
\text { Big } 4 \text { adalah EY, Deloitte, PWC, KPMG }\end{array}$ \\
\hline Leverage & $\frac{\text { Total hutang }}{\text { Total aset }} \times 100 \%$ \\
\hline Profitabilitas & $\frac{\text { Total laba bersih }}{\text { Total ekuitas }} \times 100 \%$ \\
\hline Ukuran perusahaan & Ukuran perusahaan $=\log ($ Total Aset $)$ \\
\hline
\end{tabular}

$\Delta$ Rect $=$ Perubahan hutang perusahaan $\mathrm{i}$ dalam rentang tahun ke $\mathrm{t}$

$\mathrm{e}=$ error 


\section{HASIL}

\section{Statistik Deskriptif}

Data sekunder sebagai data yang dipergunakan pada studi ini dimana objek penelitian yakni perusahaan perbankan di BEI. Datanya yang didapat diolah serta di uji menggunakan SPSS versi 25 dan program SmartPLS versi 3. Penentuan sample penelitian dapat dilihat melalui proses penentuan pada table 4.1 berikut :

\section{Tabel 4.1}

Penentuan Sampel Untuk Model Regresi Manajemen Laba

\begin{tabular}{lr}
\hline \multicolumn{1}{c}{ Keterangan } & \multicolumn{1}{c}{ Jumlah } \\
\hline Perusahaan Perbankan yang terdaftar pada BEI & 44 Perusahaan \\
Perusahaan Perbankan yang tidak memenuhi kriterianya & 5 Perusahaan \\
Perusahaan yang menjadi sampel & 39 Perusahaan \\
Tahun Penelitian & 5 Tahun \\
Jumlah data sebagai sampel penelitian & 195 Data \\
\hline
\end{tabular}

Sumber: Data Sekunder diolah (2021)

Berdasar pada penyajian tabel tersebut, bisa dilihat jumlah perseroan yang tercatat dalam BEI selama periode 2016 - 2020 terdapat 44 perusahaan. Pada periode itu memuat 5 perusahaan yang tidak memenuhi kriterianya. Oleh karenanya dapat disimpulkan perusahaan yang sesuai dengan syarat untuk dapat diteliti yaitu sejumlah 39 perusahaan dengan jumlah data keseluruhan mencapai 195 data

Table 4.2 ini akan menampilkan hasil pengolahan data dalam bentuk statistic deskriptif melalui program SPSS.

Tabel 4.2

Hasil pengujian statistik Deskriptif Variabel Non-Dummy

\begin{tabular}{|c|c|c|c|c|c|}
\hline & $\mathrm{N}$ & Minimum & Maximum & Mean & Std. Deviation \\
\hline Manajemen Laba & 195 & $-0,43$ & 0,48 & $-0,0019$ & 0,09815 \\
\hline Kepemilikan & 195 & 0,00 & 1,00 & 0,6494 & 0,32160 \\
\hline Institusional & & & & & \\
\hline $\begin{array}{l}\text { Kepemilikan } \\
\text { Manajerial }\end{array}$ & 195 & 0,00 & 0,13 & 0,0041 & 0,01723 \\
\hline $\begin{array}{l}\text { Proporsi Dewan } \\
\text { Komisaris } \\
\text { Independen }\end{array}$ & 195 & 0,00 & 1,00 & 0,5552 & 0,18417 \\
\hline Komite Audit & 195 & 1,00 & 8,00 & 3,8872 & 1,12038 \\
\hline Dewan Direktur & 195 & 3,00 & 14,00 & 6,5641 & 2,80826 \\
\hline Dewa & 195 & 0,00 & 10,00 & 3,1333 & 1,75648 \\
\hline Leverage & 195 & 0,14 & 0,93 & 0,8251 & 0,08685 \\
\hline Profitabilitas & 195 & $-0,55$ & 0,31 & 0,0240 & 0,12734 \\
\hline Ukuran Perusahaan & 195 & $\begin{array}{r}\text { Rp548.062. } \\
000.000,00\end{array}$ & $\begin{array}{r}\text { Rp1.421.790. } \\
000.000 .000,0\end{array}$ & $\begin{array}{r}\text { Rp155.086.443. } \\
733.333,3000\end{array}$ & $\begin{array}{r}\text { Rp290.318.728. } \\
684.764,75000\end{array}$ \\
\hline Valid N (listwise) & 195 & & & & \\
\hline
\end{tabular}

Sumber: Pengolahan Data Sekunder (2021)

Variable manajemen laba mempunyai nilai rata-ratanya $-0,0019$ serta nilai standar deviasinya yaitu 0,09815. Nilai mean lebih kecil daripada nilai standar deviasinya, oleh karenanya bisa disimpulkan variabel manajemen laba menunjukkan adanya variasi yang besar, berarti rata-rata manajamen labanya yang dilaksanakan perusahaan sebagai sampelnya mempunyai nilai rendah sehingga diindikasikan mayoritas perusahaannya tidak melaksanakan income smoothing.

Variabel kepemilikan institusional mempunyai nilai meannya 0,6494 serta nilai standar deviasinya yakni 0,32160. lebih besar nilai rata-ratanya dibandingkan nilai standar deviasinya, oleh karenanya ditarik kesimpulan bahwa variabel kepemilikan institusional memperlihatkan tidak 
memuat variasi besar. Hal tersebut bisa dimaksudkan bahwa kepemilikan sahamnya oleh pihak perusahaannya sebesar $64,94 \%$ dari seluruh pemegang saham.

Variabel kepemilikan manajerial nilai meannya 0,0041 serta nilai standar deviasinya 0,01723 . lebih rendah nilai rata-rata daripada nilai standar deviasinya, oleh karenanya bisa disimpulkan variabel kepemilikan manajerialnya menunjukkan adanya variasi yang besar. Hal tersebut bisa dikatakan bahwa kepemilikan saham oleh pihak manajerialnya yaitu $0,41 \%$ dari seluruh pemegang sahamnya.

Variabel proporsi dewan komisaris independent nilai meannya 0,5552 serta nilai standar deviasinya yaitu 0,18417 . lebih tinggi nilai rata-ratanya daripada nilai standar deviasinya, oleh karenanya bisa disimpulkan variable proporsi dewan komisaris independent menandakan tidak adanya variasi yang besar. Rata-rata proporsi dewan komisaris independent dari seluruh anggota dewan komisarisnya pada bagian dewan komisaris suatu perusahaan sampel sudah sesuai putusan oleh direksi PT Bursa Efek Jakarta No: Kep-305/BEJ/07-2004 mengenai Kriteria Komisaris Independen yang memaparkan banyaknya komisaris independennya pada emiten/perusahaan $\pm 30 \%$ dari semua anggota dewan komisarisnya.

Variabel komite audit bernilai rata-rata 3,8872 dan nilai standar deviasinya 1,12038. lebih tinggi nilai rata-ratanya daripada nilai standar deviasinya, oleh karenanya ditarik kesimpulan variabel komite audit menunjukkan tidak adanya variasi yang besar. Berdasar dalam aturan OJK No. 33/POJK.04/2014 menjelaskan Komite Audit minimalnya memuat 3 pihak yang asalnya dari Komisaris Independen serta golongan eksternal Perusahaan atau entitas Public. Berdasar pada hasil uji menandakan bahwa tidak sesuai ketentuan yang diberlakukan.

Variabel dewan direktur memiliki nilai rata-ratanya 6,5641 serta nilai standar deviasinya 2,80826 . lebih tinggi nilai rata-ratanya daripada nilai standar deviasinya, oleh karenanya bisa disimpulkan variabel dewan direktur memperlihatkan tidak terdapat variasi besar.Variabel dewan independen memiliki nilai mean 3,1333 di mana nilai standar deviasinya yakni 1,75648. lebih tinggi nilai rata-ratanya daripada nilai standar deviasinya, oleh karenanya bisa disimpulkan variabel dewan independen memperlihatkan tidak memuat variasi besar.

Variabel leverage mendapat angka rerata yaitu 0,8251 serta nilai standart deviasinya 0,08685 . Nilai rerata ini lebih tinggi daripada angka standart deviasinya, oleh karenanya bisa disimpulkan variabel leverage memperlihatkan tidak terdapat variasi besar.Variable profitabilitas mempunyai nilai mean 0,0240 serta nilai standar deviasinya 0,12734. Angka rerata ini lebih kecil daripada angka standart deviasinya, oleh karenanya bisa disimpulkan variable profitabilitas menunjukkan adanya variasi yang besar. Variabel ukuran suatu perusahaan bernilai rata-rata Rp155.086.443.733.333,3 dan nilai standar deviasi sebesar Rp290.318.728.684.764,75. lebih rendah nilai rata-rata daripada nilai standar deviasinya, oleh karenanya bisa disimpulkan variable ukuran perusahaannya menunjukkan adanya variasi yang besar.

Tabel 4.3

Hasil pengujian Statistik Deskriptif Variable Dummy

\begin{tabular}{llrr}
\hline \multicolumn{1}{c}{ Variable } & \multicolumn{1}{c}{ Kategori } & Frekuensi & \multicolumn{1}{c}{ Persen } \\
\hline Kualitas Audit & $1:$ BIG 4 & 111 & $56.9 \%$ \\
Total & $0:$ NON BIG 4 & 84 & $43.1 \%$ \\
\hline S & & 195 Data & $100 \%$ \\
\hline
\end{tabular}

Sumber: Data Sekunder diolah (2021)

Berdasar pada tabel tersebut variable kualitas auditor berkategori perusahaan yang memakai BIG4 serta perusahaannya yang tidak mempergunakan BIG4 menjadi KAP diperusahaannya. Bisa diperhatikan terdapat 111 data suatu perusahaan atau $56,9 \%$ perusahaannya yang memakai $B I G 4$ guna dijadikan KAP-nya. Bisa juga diperhatikan ada 84 data suatu perusahaan atau $43,1 \%$ perusahaan yang menggunakan NON BIG4 menjadi KAP-nya.

Jika disimpulkan maka hasilnya memperlihatkan perusahaan perbankan yang memakai jasa audit oleh BIG4 lebih banyak daripada perusahaan yang tidak mempergunakan jasa audit BIG4. Dan memang sudah seharusnya perusahaan perbankan menggunakan jasa audit BIG4 sebagai KAPnya untuk memastikan bahwa laporan keuangan yang dihasilkan ini wajar atau tidak wajar, dan memberikan kepercayaan yang lebih atas hasil laporan keuangan yang disediakan untuk 
Owner: Riset \& Jurnal Akuntansi

e-ISSN : 2548-9224|p-ISSN : 2548-7507

Volume 6 Nomor 1, Januari 2022

masyarakat, investor, karyawan, prinsipal dan pihak lainnya yang memerlukan laporan keuangan tersebut.

\section{Hasil Evaluasi Model}

Hasil dari desain penelitian ditentukan oleh kualitas dari masing-masing variabel, sehingga penjelasan pengujian dari tiap variabelnya diantaranya:

\section{Hasil Uji Inner Model}

Pengaruh secara langsung atau tidak ada kaitan dengan variabel laten yang diprediksi dengan berjalannya model internal (Hair et al., 2011)

Tabel 4.12

Hasil uji Pengaruh Langsung

\begin{tabular}{|c|c|c|c|c|}
\hline Jalur & T Statistic & P Value & Hasil & Kesimpulan \\
\hline $\begin{array}{l}\text { Kepemilikan Institusional -> } \\
\text { Manajemen Laba }\end{array}$ & 2,69014 & 0,04043 & H1 Signifikan Positif & H1 Diterima \\
\hline $\begin{array}{l}\text { Kepemilikan Manajerial -> } \\
\text { Manajemen Laba }\end{array}$ & 2,35476 & 0,02292 & H2 Signifikan Positif & H2 Diterima \\
\hline $\begin{array}{l}\text { Proporsi Dewan Komisaris } \\
\text { Independen -> Manajemen } \\
\text { Laba }\end{array}$ & 3,88744 & 0,03968 & H3 Signifikan Positif & H3 Diterima \\
\hline $\begin{array}{l}\text { Komite Audit -> Manajemen } \\
\text { Laba }\end{array}$ & 2,13754 & 0,00066 & H4 Signifikan Positif & H4 Diterima \\
\hline $\begin{array}{l}\text { Dewan Direktur -> } \\
\text { Manajemen Laba }\end{array}$ & 2,29003 & 0,01915 & H5 Signifikan Positif & H5 Diterima \\
\hline $\begin{array}{l}\text { Dewan Independen -> } \\
\text { Manajemen Laba }\end{array}$ & 2,90358 & 0,03665 & H6 Signifikan Positif & H6 Diterima \\
\hline $\begin{array}{l}\text { Kualitas Audit -> } \\
\text { Manajemen Laba }\end{array}$ & 2,55924 & 0,04625 & H7 Signifikan Positif & H7 Diterima \\
\hline $\begin{array}{l}\text { Leverage -> Manajemen } \\
\text { Laba }\end{array}$ & 2,73589 & 0,04214 & H8 Signifikan Positif & H8 Diterima \\
\hline $\begin{array}{l}\text { Profitabilitas -> Manajemen } \\
\text { Laba }\end{array}$ & 3,28978 & 0,01772 & H9 Signifikan Positif & H9 Diterima \\
\hline $\begin{array}{l}\text { Kepemilikan Institusional x } \\
\text { Ukuran Perusahaan -> } \\
\text { Manajemen Laba }\end{array}$ & 2,047 & 0,01104 & H10 Signifikan Positif & $\begin{array}{l}\mathrm{H} 10 \\
\text { Diterima }\end{array}$ \\
\hline $\begin{array}{l}\text { Kepemilikan Manajerial x } \\
\text { Ukuran Perusahaan -> } \\
\text { Manajemen Laba } \\
\text { Proporsi Dewan Komisaris }\end{array}$ & 2,27539 & 0,00313 & H10 Signifikan Positif & $\begin{array}{l}\mathrm{H} 10 \\
\text { Diterima }\end{array}$ \\
\hline $\begin{array}{l}\text { Independen x Ukuran } \\
\text { Perusahaan -> Manajemen } \\
\text { Laba }\end{array}$ & 2,13308 & 0,00418 & H10 Signifikan Positif & $\begin{array}{l}\mathrm{H} 10 \\
\text { Diterima }\end{array}$ \\
\hline $\begin{array}{l}\text { Komite Audit x Ukuran } \\
\text { Perusahaan -> Manajemen } \\
\text { Laba }\end{array}$ & 2,01978 & 0,00422 & H10 Signifikan Positif & $\begin{array}{l}\mathrm{H} 10 \\
\text { Diterima }\end{array}$ \\
\hline $\begin{array}{l}\text { Dewan Direktur x Ukuran } \\
\text { Perusahaan -> Manajemen } \\
\text { Laba }\end{array}$ & 2,44548 & 0,04616 & H10 Signifikan Positif & $\begin{array}{l}\mathrm{H} 10 \\
\text { Diterima }\end{array}$ \\
\hline $\begin{array}{l}\text { Dewan Independen x } \\
\text { Ukuran Perusahaan -> } \\
\text { Manajemen Laba }\end{array}$ & 2,18886 & 0,00028 & H10 Signifikan Positif & $\begin{array}{l}\mathrm{H} 10 \\
\text { Diterima }\end{array}$ \\
\hline
\end{tabular}


Owner: Riset \& Jurnal Akuntansi

e-ISSN : 2548-9224|p-ISSN : 2548-7507

Volume 6 Nomor 1, Januari 2022

$\begin{array}{lcccl}\begin{array}{l}\text { Kualitas Audit x Ukuran } \\ \text { Perusahaan -> Manajemen } \\ \text { Laba }\end{array} & 2,57325 & 0,04673 & \text { H10 Signifikan Positif } & \begin{array}{l}\text { H10 } \\ \text { Diterima }\end{array} \\ \begin{array}{l}\text { Leverage x Ukuran } \\ \begin{array}{l}\text { Perusahaan -> Manajemen } \\ \text { Laba }\end{array}\end{array} & 2,31615 & 0,00202 & \text { H10 Signifikan Positif } & \text { H10 } \\ \begin{array}{l}\text { Profitabilitas x Ukuran } \\ \text { Perusahaan -> Manajemen }\end{array} & 2,39253 & 0,03484 & \text { H10 Signifikan Positif } & \text { H10 } \\ \begin{array}{l}\text { Laba } \\ \text { Ukuran Perusahaan -> }\end{array} & & & & \text { H10 } \\ \text { Manajemen Laba } & 2,46943 & 0,03897 & \text { H10 Signifikan Positif } & \text { Diterima }\end{array}$

Sumber : Pengolahan Data sekunder (2021)

\section{Hasil Uji Koefisien Determinasi}

Penggunaan koefisien determinasi ini guna melihat hubungan antar variable bebasnya. $\mathrm{R}^{2}$ dari variable dependen manajemen laba adalah 0,860 atau $86,0 \%$. Hasil ini memperlihatkan variable dependen manajemen laba dapat diuraikan oleh variabel independennya yakni $86,0 \%$, sementara sisanya $14,0 \%$ dipaparkan oleh variable lainnya yang tidak diteliti pada studi ini.

Tabel 4.14

Hasil Uji Koefisien Determinasi

\begin{tabular}{lc}
\hline & R Squared \\
\hline Manajemen Laba & 0,860 \\
\hline \hline
\end{tabular}

Sumber: Pengolahan Data sekunder (2021)

\section{PEMBAHASAN}

\section{Kepemilikan Institusional terhadap manajamen laba}

Path coefficients dinyatakan memengaruhi bila tingkat signifikansinya 5\% dari nilai T-statistic $>1,96$ atau P-values 0.05. Hasil variable kepemilikan institusional terhadap manajemen labanya memiliki pengaruh signifikan positif, karena nilai $\mathrm{t}$-statistic $>1,96$, nilai $\mathrm{P}$ Value $<0,05$, jadi bisa disimpulkan hipotesis 1 diterima. Saleem dan Alzoubi (2016) menemukan bahwa semakin banyak investor yang terlibat maka akan memberikan dampak positif pada perilaku perusahaan yang hal ini akan membuat manajer lebih berkecil hati untuk melaksanakan manajemen laba sebab penekanan oleh kepemilikan investor. Hasil ini konsisten dari penelitian Istikhomah dan Widyawati (2018), Sumbari et al. (2017), Dina dan Dul (2012), Kusumaningtyas (2012), Saidu et al. (2017), Djamaludin dan Handayani (2018).

\section{Kepemilikan Manajerial terhadap manajemen laba}

Nilai yang dihasilkan data kepemilikan manajerial terhadap manajemen labanya membuktikan ada pengaruh signifikan positif, karena nilai t hitung $>1,96$, serta angka $P$ Value $<0,05$, oleh karena itu hipotesis 2 diterima. Semakin besar saham dari manajerial, maka semakin kecilnya suatu perusahaan melaksanakan praktik manajemen laba. Hal tersebut karena laba yang besar membuat perusahaannya berkecil hati melakukan manipulasi laba (Fitri et al., 2018). Hasil ini konsisten dari studi Fitri et al (2018), Mahiswari dan Nugroho (2014), Agustia (2013), Abata dan Migiro (2016), Amperaningrum dan Sari (2013), Ariesanti (2015), Haslinda et al. (2019), Jao dan Pagulung (2011), Jensen dan Meckling (2016), Lidiawati dan Asyik (2016).

\section{Proporsi Dewan Komisaris Independen terhadap manajemen laba}

Hasil variabel proporsi dewan komisaris independen terhadap manajemen labanya berpengaruh secara signifikan positif, karena hasil t hitung $>1,96$, serta angka P Value $<0,05$, jadi bisa diputuskan hipotesis 3 diterima. Semakin besarnya jumlah dewan komisaris independen pada perusahaannya, maka kian kecilnya perusahaan melakukan manajemen laba. Hal tersebut karena 
jumlah dewan komisaris independen yang banyak membuat perusahaannya berkecil hati melakukan manipulasi laba (Fitri et al., 2018). Hasil tersebut serupa dari riset Kodriyah et al (2017), Ayem dan Yuliana (2019), Karina dan Sufiana (2020), Oktariani dan Africano (2017), Susanto dan Christiawan (2016).

\section{Komite Audit terhadap manajemen laba}

Dari pengujian data komite audit pada manajemen laba diketahui memiliki pengaruh secara signifikan positif, karena angka thitung $>1,96$, serta angka $\mathrm{P}$ Value $<0,05$, oleh karena itu hipotesis 4 diterima. Semakin besarnya jumlah komite audit diperusahaan, maka semakin kecil perusahaan melaksanakan praktik manajemen laba. Hal tersebut sebab jumlah komite audit yang banyak membuat perusahaannya berkecil hati melakukan manipulasi laba (Istikhomah \& Widyawati, 2018). Hasil tersebut sebagaimana studi Yogi et al. (2016), Dina dan Dul (2012), Kusumaningtyas (2012), Saidu et al. (2017), Djamaludin dan Handayani (2018).

\section{Dewan Direktur terhadap manajemen laba}

Nilai yang dihasilkan data dewan direktur pada manajemen laba memiliki pengaruh secara signifikan positif, karena hasil t hitung $>1,96$ serta angka $\mathrm{P}$ Value $<0,05$, oleh karena itu hipotesis 5 diterima. Semakin besarnya jumlah dewan direktur diperusahaannya, maka semakin kecilnya perusahaan melaksanakan praktik manajemen laba. Hal ini karena jumlah dewan direktur yang banyak membuat perusahaan berkecil hati melakukan manipulasi laba (Istikhomah \& Widyawati, 2018). Hasil ini konsisten dari penelitian Mayliza et al. (2019), Swastika (2013), Dwiridotjahjono et al. (2019), Fodio et al. (2013), Karuniasih (2013), Laksana (2015), Palma dan Purba (2020), Pratiwi et al. (2016), Putra (2019), Ricardo dan Faisal (2015).

\section{Dewan independent terhadap manajemen laba}

Nilai yang dihasilkan data dewan independen pada manajemen laba membuktikan terdapatnya pengaruh secara signifikan positif, karena angka t hitung $>1,96$, nilai $\mathrm{P}$ Value $<0,05$, jadi bisa ditentukan hipotesis 6 diterima. Semakin tinggi tingkatannya disuatu perusahaan, maka semakin kecil kemungkinannya guna terlibat dalam melaksanakan manajemen laba (Abata \& Migiro, 2016). Hasil ini konsisten dari penelitian Mandalika dan Hermanto (2020), Maulidah dan Santoso (2020), Oktariani dan Africano (2017), Palma dan Purba (2020), Pratiwi et al. (2016), Ricardo dan Faisal (2015), sedangkan hasil ini beda dari penelitian Kusumaningtyas (2012), Saidu et al. (2017) menandakan dewan independen berpengaruh signifikan negatif pada manajemen labanya.

\section{Kualitas audit terhadap manajemen laba}

Nilai yang dihasilkan variable kualitas audit pada manajemen laba membuktikan terdapatnya pengaruh secara signifikan positif, karena angka thitung $>1,96$, serta angka $\mathrm{P}$ Value $<0,05$, jadi bisa ditentukan hipotesis 7 diterima. Semakin besar kualitas auditnya dalam sebuah perusahaan, maka semakin kecilnya perusahaan melaksanakan praktik manajemen laba. Sebab kualitas audit yang baik membuat perusahaan berkecil hati melakukan manipulasi laba (Istikhomah \& Widyawati, 2018). Hasil tersebut sesuai dari studi Haslinda et al. (2019), Jao dan Pagulung (2011), Jensen dan Meckling (2016), Karina dan Sufiana (2020), Karuniasih (2013), Laksana (2015).

\section{Leverage terhadap manajemen laba}

Nilai yang dihasilkan data leverage terhadap manajemen laba memiliki pengaruh secara signifikan positif, karena angka t hitung $>1,96$, serta angka $\mathrm{P}$ Value $<0,05$, jadi bisa ditentukan hipotesis 8 diterima. Semakin besarnya leverage memperlihatkan dana pemiliknya dalam pembiayaan investasi perusahaannya semakin kecil, ataupun tingkat pemakaian utang oleh perusahaannya semakin naik (Muhammadinah, 2016). Hasil ini konsisten dari penelitian Istikhomah dan Widyawati (2018), Fitri et al (2018), Mahiswari dan Nugroho (2014), Agustia (2013), Kodriyah et al (2017), Mayliza et al. (2019), Swastika (2013), Abata dan Migiro (2016), Amperaningrum dan Sari (2013), Ariesanti (2015), Ayem dan Yuliana (2019). 


\section{Profitabilitas terhadap manajemen laba}

Hasil variabel profitabilitas terhadap manajemen labanya memiliki pengaruh signifikan positif, karena angka thitung $>1,96$, serta angka $\mathrm{P}$ Value $<0,05$, jadi bisa ditentukan hipotesis 9 diterima. Semakin tingginya laba yang dihasilkan perusahaannya maka akan semakin tingginya return yang diinginkan investornya sehingga perusahaannya perlu terus memperbaiki kinerja mereka dalam mengelola perusahaan supaya memperoleh laba yang diinginkan dan membuat investor merasa puas melakukan investasi di perusahaan tersebut, sehingga membuat perusahaan berkecil hati melakukan praktik manajemen laba (Haslinda, Mardani \& Wahono, 2019). Hasil tersebut sama dengan riset Palma dan Purba (2020), Pratiwi et al. (2016), Ricardo dan Faisal (2015), Shohlihin dan Ratmono (2020), Sulistyanto (2014) menandakan profitabilitas memengaruhi signifikan positif pada manajemen labanya.

\section{Ukuran perusahaan sebagai variable moderasi}

Variable ukuran perusahaannya sebagai variabel moderasi merupakan interaksi diantara kepemilikan institusional dan manajerial, proporsi dewan komisaris, komite audit, dewan direktur, dewan independen, kualitas audit, leverage dan profitabilitas ternyata signifikan, oleh karenanya disimpulkan variable ukuran perusahaannya merupakan variabel moderating. Tambah tinggi aset yang terdapat paada sebuah perusahaan, maka kian rendah kemungkinan perusahaannya melaksanakan praktik manajemen labanya (Istikhomah \& Widyawati, 2018). Hasil ini konsisten dari penelitian Yasser dan Soliman (2018), Yogi et al. (2016), Dina dan Dul (2012), Lidiawati dan Asyik (2016), Mandalika dan Hermanto (2020).

\section{KESIMPULAN}

Penelitian dilakukan untuk melakukan pengujian terhadap pengaruh kepemilikan institusional dan manajerial, proporsi dewan komisaris independen, dewan direktur, komite audit, kualitas audit, dewan independen, leverage, profitabilitas yang dimana ukuran perusahaannya memoderasi terjadi manajemen laba. Berdasarkan analisis dari pengujiannya, maka dapat disimpulkan bahwa variable kepemilikan institusional $\left(\mathrm{X}_{1}\right)$, kepemilikan manajerial $\left(\mathrm{X}_{2}\right)$, proporsi dewan komisaris independen $\left(\mathrm{X}_{3}\right)$, komite audit $\left(\mathrm{X}_{4}\right)$, dewan direktur $\left(\mathrm{X}_{5}\right)$, dewan independen $\left(\mathrm{X}_{6}\right)$, kualitas audit $\left(\mathrm{X}_{7}\right)$, leverage $\left(\mathrm{X}_{8}\right)$, profitabilitas $\left(\mathrm{X}_{9}\right)$ mempunyai pengaruh signifikan positif. Variable ukuran perusahaan $\left(\mathrm{X}_{10}\right)$ bisa jadi variabel moderasi untuk kepemilikan institusional, kepemilikan manajerial, proporsi dewan komisaris independent, komite audit, dewan direktur, dewan independen, kualitas audit, leverage dan profitabilitas dapat menjadi variabel moderasi terhadap manajemen laba dan ukuran perusahaan bisa jadi variabel moderasi terhadap manajemen laba. Hasil uji tersebut searah dengan Sembilan belas hipotesis dan bisa diterima. Perbedaan hasil uji pada penelitian sebelumnya dapat dikarenakan ketidaksamaan pengukuran, dan tahun penelitian yang digunakan.

\section{REFERENSI}

Abata, M. A., \& Migiro, S. O. (2016). Corporate governance and management of earnings: Empirical evidence from selected Nigerian-listed companies. Investment Management and Financial Innovations, 13(2), 189-205. https://doi.org/10.21511/imfi.13(2-1).2016.07

Agustia, D. (2013). Pengaruh Faktor Good Corporate Governance, Free Cash Flow, dan Leverage Terhadap Manajemen Laba. Jurnal Akuntansi Dan Keuangan, 15(1), 27-42. https://doi.org/10.9744/jak.15.1.27-42

Amijaya, M. D., \& Prastiwi, A. (2013). Pengaruh Kualitas Audit Terhadap Manajemen Laba. Diponegoro Journal of Accounting, 2(3), 1-13. https://doi.org/10.9744/jak.16.1.52-62

Ariesanti, D. D. (2015). Pengaruh mekanisme GCG dan Financial distress terhadap manajemen laba. Implementation Science, 39(1), 1-15. http://dx.doi.org/10.1016/j.biochi.2015.03.025\%0Ahttp://dx.doi.org/10.1038/nature10402\% 0Ahttp://dx.doi.org/10.1038/nature21059\%0Ahttp://journal.stainkudus.ac.id/index.php/equil ibrium/article/view/1268/1127\%0Ahttp://dx.doi.org/10.1038/nrmicro2577\%0Ahttp:// 
Ayem, S., \& Yuliana, D. (2019). Pengaruh Independensi Auditor, Kualitas Audit, Manajemen Laba , Dan Komisaris Independen Terhadap Integritas Laporan Keuangan ( Studi Kasus Pada Perusahaan Perbankan Yang Terdaftar di BEI. 16(1).

Fitri, A., Muda, I., \& Badaruddin. (2018). The Influence of Good Corporate Governance, Leverage, and Profitability on Earning Management with Firm Size as Moderating Variable in the Banking Companies Listed In Indonesia Stock Exchange in the Period of 2012-2016. International Journal of Research and Review, 5(9), 49-66.

Haslinda, N., Mardani, R. M., \& Wahono, B. (2019). Pengaruh Ukuran Perusahaan, Leverage dan Profitabilitas Terhadap Nilai Perusahaan (Studi Kasus pada Perusahaan Perbankan yang terdaftar di Bursa Efek Indonesia Tahun 2015-2017). 8(1), 127-141.

Istikhomah, M., \& Widyawati, D. (2018). Jurnal Ilmu dan Riset Akuntansi e-ISSN: 2460-0585. Pengaruh Good Corporate Governance, Leverage, Dan Ukuran Perusahaan Terhadap Manajemen Laba, 7(7).

Jao, R., \& Pagalung, G. (2011). Corporate Governance, Ukuran Perusahaan, dan Leverage Terhadap Manajemen Laba Perusahaan Manufaktur Indonesia. Jurnal Akuntansi Dan Auditing, 8(1), 43-54.

Karina, R., \& Sufiana, S. (2020). Pengaruh Efektivitas Komite Audit, Kualitas Audit Dan Efektivitas Dewan Direksi Terhadap Manajemen Laba. Journal of Applied Managerial Accounting, 4(1), 42-59. https://doi.org/10.30871/jama.v4i1.1925

Kodriyah, Suprihatin, N. S., \& Octavani, S. (2017). Peran Dewan Pengawas Syariah, Komite Audit Dan Dewan Komisaris Dalam Mendeteksi Praktik Manajemen Laba. Jurnal Akuntansi, 4(2), 59-64.

Lidiawati, N., \& Asyik, N. F. (2016). Pengaruh Kualitas Audit, Komite Audit, Kepemilikan Institusional, Ukuran Perusahaan Terhadap Manajemen Laba. Jurnal Ilmu Dan Riset Akuntansi, 5(5), 1-19.

Mahiswari, R., \& Nugroho, P. I. (2014). Pengaruh Mekanisme Corporate Governance, Ukuran Perusahaan dan Leverage Terhadap Manajemen Laba dan Kinerja Keuangan. Jurnal Ekonomi Dan Bisnis, 17(1), 1. https://doi.org/10.24914/jeb.v17i1.237

Maulidah, R., \& Santoso, R. A. (2020). Pengaruh kualitas audit, ukuran perusahaan dan leverage terhadap manajemen laba pada perusahaan perbankan yang tercatat dibursa efek indonesia tahun 2016-2018. Jurnal Mahasiswa Manajemen, 01(01), 56-69.

Mayliza, R., Sutra Dewi, A., \& Fitria Sari, L. (2019). The Influence of Good Corporate Governance Towards Financial Performance Using Earnings Management As the Intervening Variable at Banking Companies Listed in Indonesia's Stock Exchange. KnE Social Sciences, 3(14), 472. https://doi.org/10.18502/kss.v3i14.4332

Muhammadinah. (2016). Struktur Kepemilikan Manajerial Dan Dividend Payout Ratio Terhadap Manajemen Laba Pada Perusahaan Sektor Perbankan Yang Terdaftar di Bursa Efek Indonesia. I-Finance, 2(1), 35-54.

Oktariani, Y., \& Africano, F. (2017). Pengaruh Corporate Governance Terhadap Nilai Perusahaan Pada Perusahaan Perbankan Yang Terdaftar Di Bei Tahun 2011-2014. Jurusan Akuntansi STIE Multi Data Palembang, 17(2), pp: 145-168.

Palma, I., \& Purba, N. M. (2020). Pengaruh Tata Kelola Perusahaan Dan Struktur Kepemilikan Terhadap Manajemen Laba Yang Terdaftar Di Bursa Efek Indonesia. Jurnal EMBA: Jurnal 
Owner: Riset \& Jurnal Akuntansi

e-ISSN : 2548-9224 | p-ISSN : 2548-7507

Volume 6 Nomor 1, Januari 2022

DOI : https://doi.org/10.33395/owner.v6i1.656

Riset Ekonomi, Manajemen, Bisnis Dan Akuntansi, 8(1). https://doi.org/10.35794/emba.v8i1.28018

Saleem, E., \& Alzoubi, S. (2016). Disclosure quality and earnings management: Evidence from Jordan. Accounting Research Journal, 29(1), 2-3. https://doi.org/10.1108/ARJ-02-2016-0015

Shohlihin, M., \& Ratmono, D. (2020). ANALISIS SEM-PLS dengan Warp-PLS 7.0 untuk Hubungan Nonlinier dalam penelitian Sosial dan Bisnis. https://books.google.co.id/books?hl=id\&lr=\&id=NbMWEAAAQBAJ\&oi=fnd\&pg=PP1\&d $\mathrm{q}=$ teknik+analisis+data+kuantitatif+menggunakan+PLS\&ots=X5bDz72qaX\&sig=tGMCMf P3ZNTDrLonSbBSNnOLKI8\&redir_esc $=\mathrm{y} \# \mathrm{v}=$ onepage $\& \mathrm{q} \& \mathrm{f}=$ false

Swastika, D. L. T. (2013). Corporate Governance, Firm Size, and Earning Management: Evidence in Indonesia Stock Exchange. IOSR Journal of Business and Management, 10(4), 77-82. https://doi.org/10.9790/487x-1047782

Wimelda, L., \& Chandra, A. (2018). Accounting and Finance Review Opportunistic Behavior, External Monitoring Mechanisms, Corporate Governance, and Earnings Management. Acc. Fin. Review, 3(1), 44-52.

Yogi, L. M. dwi P., \& Damayanthi, I. G. A. E. (2016). Pengaruh Arus Kas Bebas, Capital Adequacy Ratio Dan Good Corporate Governance Pada Manajemen Laba. Jurnal Akuntansi Universitas Udayana 15(2), 1056-1085. 